\title{
SPOT-4 号業務運用の一部開始
}

新しい RS 衛星の登場が待ち望まれているなかで, 本年 3 月 24 日に SPOT -4 号が打ち上げられた。その後 順調な試験運転を経て，このたび業務運用の一部が開 始されるはこびとなった。

SPOT -4 号は, 大別して 2 種類のセンサを搭載して いる。まず従来の SPOT-1,2,3 号に搭載されていた HRV-XS, PA を発展的に継承したHRVIR と, 新規 に搭載されたセンサであるVEGETATION の 2 つで ある。今回, 運用が一部開始されたのは, 前者の HRVIR に関してである。

HRVIR は観測幅 $60 \mathrm{~km}$, パンクロ $10 \mathrm{~m}$, マルチ (緑, 赤, 近赤外, 短波長赤外) $20 \mathrm{~m}$ の地上分解能を有してお $\eta$, 従来の HRV の延長線上にあるが, 大きく改良され た部分は，短波長赤外が加わった点にある。この波長 域はLANDSAT-TM においてはバンド 5 に対応し ており, 裸地等の土地被覆識別能力がLANDSAT -TM データに近づくことが期待される。図 1 は SPOT -4 号によるHRVIR の初観測画像と伝えられ ているものであり，観測日は打ち上げ 3 日後の1998年 3 月27日である。場所はハンガリー, ブダペストから 南へ $150 \mathrm{~km}$ ほどの小都市バヤである。画像中央の川は ドナウ河である。赤外カラーの合成内容は, 短波長赤 外領域を赤, 近赤外領域を緑, 緑領域を青に振り分け て表示している。画像上で明るい緑色は農作物等の植 生，深い緑色は樹木，赤または茶色は裸地を示してい
る。平坦地の河川の蛇行状態と土地利用が興味深く映 し出されている。

いっぽう新規に搭載されたセンサVEGETATION は，来年1999年 1 月の運用をめざして地上の集中処理 施設の建設が現在進められている。VEGETATION は, 1 日でほぼ地球全域を観測でき，地上分解能は 1 $\mathrm{km}$ ，観測幅は約 $2,200 \mathrm{~km}$ である。既存のセンサでは NOAA-AVHRR と類似した仕様を有している。波長 帯域は青, 赤, 近赤外, 短波長赤外の 4 バンドを有し ており，分光内容は青領域を除けば同時搭載の HRVIR と対応した仕様となっている。このため VEGETATION で広範囲を観測し，画像内の一部を HRVIR で詳細に観測することが可能であり，標本地 区の現地照合が $1 \mathrm{~km}$ 画素の VEGETATION に対し てでも，HRVIRを仲介することで，比較的容易におこ なえることが期待される。

図 2 はインド・パキスタン地域を1998年 4 月 2 日に VEGETATION により観測したデータの赤外カラー 合成画像である。近赤外領域を赤く表示している。イ ンダス河流域に植生が分布している状態が明瞭に確認 できる。これらの地域はインダス河からの貴重な潅溉 水で植生が保持されている。

VEGETATION の運用が来年から開始されれば, 今回開始の HRVIR との併用で地球規模の環境監視 によりいっそうの活用が期待される。
*株式会社 エア・グラフ Air-Graph Co.

「写真測量とリモートセンシング」VOL. 37, NO. 4, 1998 


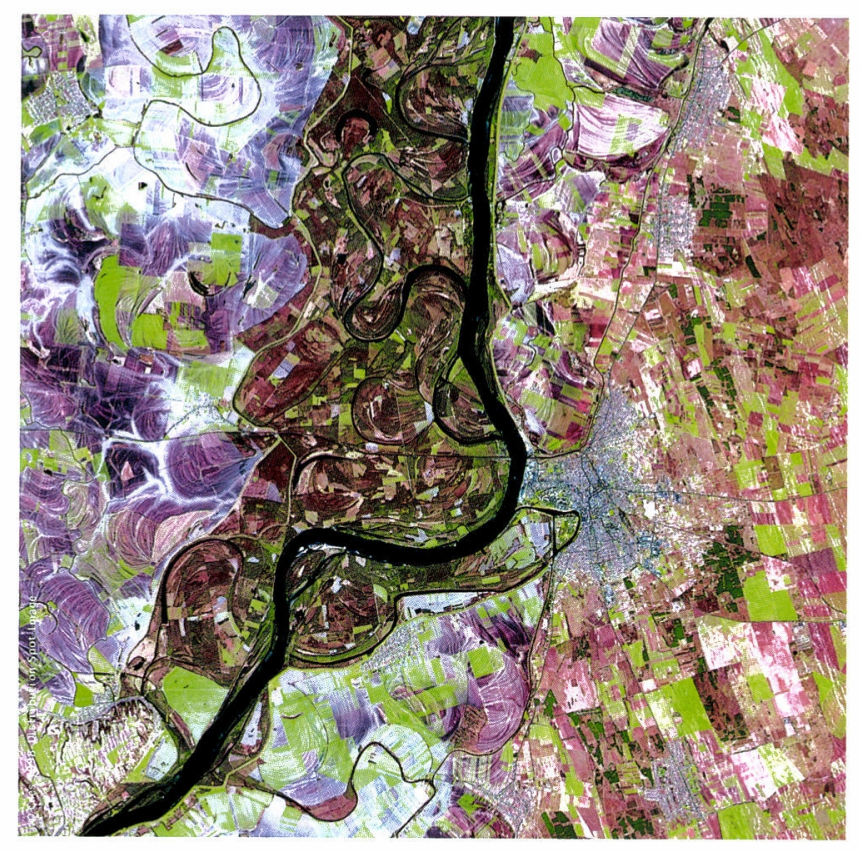

図 1 SPOT4 HRVIR 赤外カラー合成画像 1998年 3 月27日観測 バヤ周辺地区（ハンガリー） (C) Cnes 1998-Distribution Spot Image/RESTEC

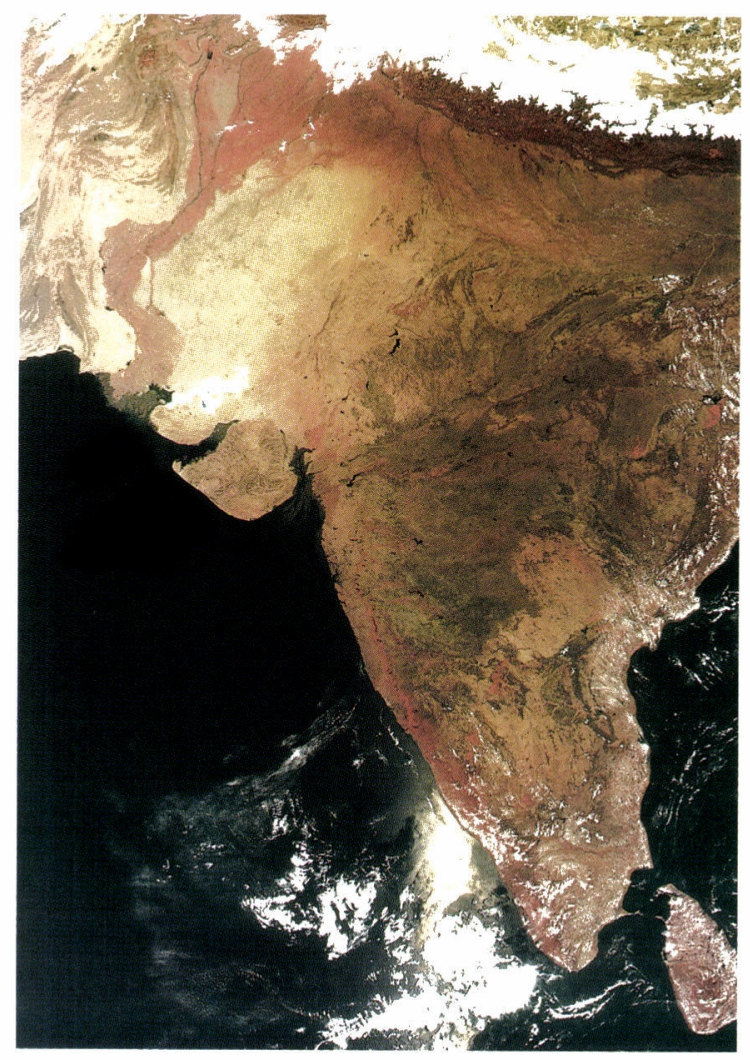

図 2 SPOT4 VEGETATION 赤外カラー合成画像 1998年 4 月 2 日観測 インド・パキスタン地域 (C) Cnes 1998-Distribution Spot Image/RESTEC 